\title{
СИНТЕЗ И ИССЛЕДОВАНИЕ НОВЫХ МОЛЕКУЛЯРНЫХ ПЕРЕКЛЮЧАТЕЛЕЙ НА ОСНОВЕ ПРОИЗВОДНЫХ ПИРАЗОЛА И ИЗАТИНА СО СПИРОПИРАНОВЫМ ФРАГМЕНТОМ
}

\author{
Е.А. Жегулович, М.Ю. Селиверстов, Н.А. Лозинская \\ Московский государственный университет имени М.В. Ломоносова, химический \\ факультет, 119991, Москва, Россия, Ленинские горы д.1 стр.3.
}

DOI: 10.19163/MedChemRussia2021-2021-248

E-mail: klavrik97@mail.ru

Среди известных молекулярных переключателей выдающимися свойствами обладают представители класса спиропиранов. Их соединения демонстрируют обширный диапазон чувствительности к свету, изменениям температуры и pH, окислительно-восстановительным процессам, что может оказаться полезным для различных медицинских целей [1]. В настоящей работе индолин-пирановые красители [2] стали прототипом для создания новых цианиновых производных на основе пиразола, в которых потенциально возможно внутри-молекулярное нуклеофильное присоединение с образованием спиропиранового фрагмента. Была разработана общая методика синтеза данных соединений, включающая конденсацию пиразолиевых солей с активной метиленовой компонентой с рядом ароматических гидрокси альдегидов либо с рядом изатиновых производных в присутствии основания.

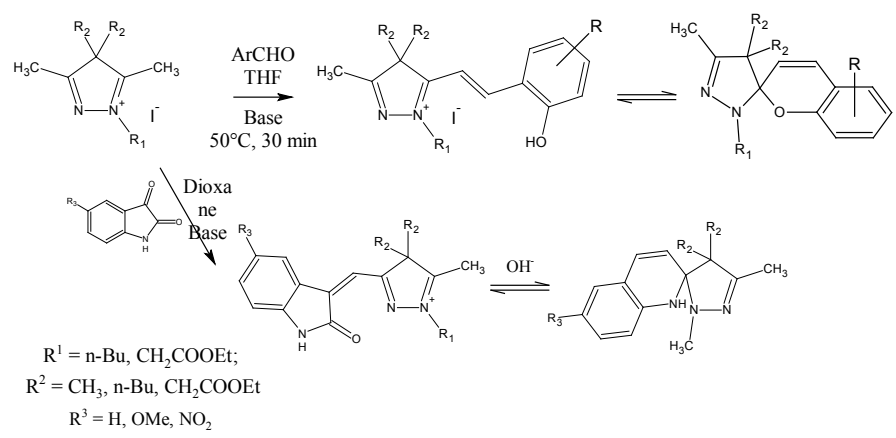

Для некоторых полученных соединений характерны фото-, сольвато- и ацидохромизм. Исследования на разных клеточных культурах показали низкую цитотоксичность производных на основе ароматических альдегидов, что открывает возможности к их применению в качестве биомаркеров, а продукты на основе изатинов могут потенциально иметь заметную активность к рецепторам MT3, отвечающим за снижение внутриглазного давления.

\section{Литература}

1. Klajn R., "Spiropyran-based dynamic materials" // Chemical Society Reviews, 2014, v.43, №1, pp. 148-184.

2. Fischer E., Hirshberg Y., "Formation of coloured forms of spiropyrans by low-temperature irradiation" // Journal of the Chemical Society, 1952, pp. 4522-4524. 